\begin{tabular}{l|l|l|l|l}
\hline Volume 1 & Issue 1 & February (2021) & DOI: 10.47540/ijias.v1i1.160 & Page: $1-11$ \\
\hline
\end{tabular}

\title{
Assessment of "Musa spp" Fibre Inclusion on the Strength and Sorption Properties of Cement Bonded Particle Board
}

\author{
Jacob Mayowa Owoyemi ${ }^{1}$, Adigun Hazzan Opeyemi ${ }^{2}$ \\ ${ }^{1}$ Forestry and Wood Technology Department, Nigeria \\ ${ }^{2}$ Federal University of Technology Akure, Nigeria
}

Corresponding Author: Adigun Hazzan Opeyemi; Email: ahazzan23@gmail.com

\author{
A R T I C LE IN F O \\ Keywords: Banana Stem, CBBP, Fibre \\ Inclusion, Sorption and Strength \\ Properties. \\ Received : 15 December 2020 \\ Revised : 25 January 2021 \\ Accepted : 07 February 2021
} \begin{abstract}
A B S T R A C T
The increase in demand for wood for various purposes has put serious pressure on Nigeria's forest with its attendant fall in the supply of solid wood for construction purposes. As an alternative, non-woody material like banana stem fibre is being investigated for the production of Cement Bonded Particle Board (CBPB). The sorption and strength properties of CBPB from Musa spp fibre were assessed. The board samples were formed using cement to materials mixing ration of 2:1 and 3:1 and blending proportions of sawdust and banana fibre using ordinary Portland cement as a binder. Physical and Mechanical properties of boards produced from stem using were investigated. The influence of blending proportion (B.P) and mixing ratio (MR) on Density, Water Absorption (WA), Thickness Swelling (TS), Linear Expansion, Modulus of Rupture (MOR), and Modulus of Elasticity (MOE) were determined. The results of sorption properties showed that for immersion at 24, 48, and 72 hours, WA, TS, and LE decreased with an increase in mixing ratio. MOE mean values ranged between 293.65 and $2367.01 \mathrm{~N} / \mathrm{mm}^{2}$ for $2: 1$ and 250.99 and $2009.28 \mathrm{~N} / \mathrm{mm}^{2}$ for $3: 1$ while MOR values ranged between 2.55 and 7.592 $\mathrm{N} / \mathrm{mm}^{2}$ for $2: 1$ and ranged from 0.55 to $1.40 \mathrm{~N} / \mathrm{mm}^{2}$ for $3: 1$ respectively. The result proved that banana fibre is suitable for the production of panel products with enhanced strength properties.
\end{abstract}

\section{INTRODUCTION}

Today, the multi-faceted demand for woodproducts by the growing population has resulted in over-exploitation and declined forest resources (Owoyemi et al., 2010). As a result, the panel-board industry is showing an increasing interest in the utilization of wastes from sawmills and furniture mills in the production of panel-boards to mitigate the rate of forest exploitation and to promote sustainable forest management. Studies conducted in the past have shown that wood-wastes and agricultural residues such as wheat straw (Mantanis and Berns, 2001), maize (Ajayi, 2010), maize stalk (Ajayi, 2002), yam stem (Ajayi, 2006), and bamboo (Papadopoulos et al., 2004) are suitable for particleboard production.
Particle Board (PB) is a composite material and engineered wood products produced from sawdust, chips of wood, sawmill shavings, and a synthetic resin, glue, or other suitable binders (Bruce, 2000). The constituents are pressed in wide flat boards or sheets of uniform cross-section and thickness under pressure and heat in a suitable mold after mixing.

In Particle Board production, the original longitudinal grain arrangement of solid wood is reformed by gluing wood particles together so that they criss-cross each other to form a network of structures with no general grain direction (Adejoba et al., 2009). The manufactured board in final form thereby retains few properties of the original wood and because of the manufacturing 
process, gains new and different properties (Wood Handbook, 1999).

The utilization of agricultural residues and pozzolan cement in the manufacturing of ceilingboard is a suitable alternative to sawn timber, sawdust, among others (Owoyemi et al., 2010) thereby, forests are managed sustainably. The pozzolan-bonded board is useful as a construction material in regions where fire and moisture interdict the utilization of resin-bonded particleboard (Aruwajoye, 2008).

Banana Pseudo-stem is the part of banana plant observed as trunk, they are fleshy, consist of water, and anatomically lack vascular bundles like the sclerenchyma, parenchyma that are found in a tree. The pseudo-stem can support a bunch weight of $50 \mathrm{~kg}$ or more, they are usually left on the field after harvesting where it deteriorates rendering it as waste material. Post-harvest banana pseudo-stem residues are potential raw material for particleboard production in some areas of the country where it's available in large quantities e.g. Ogun, Ondo, Ekiti, Edo, and Cross-River (Ajayi, 2003).

Proper management and utilization of agricultural residues could generate employment opportunities, increase the economic standards of farmers and provide other services for the public and industries. This may be the best option for mitigating global climate change. However, utilization of the renewable resources in cementbonded boards could be a suitable alternative in furniture industries (Aladenola et al., 2008).

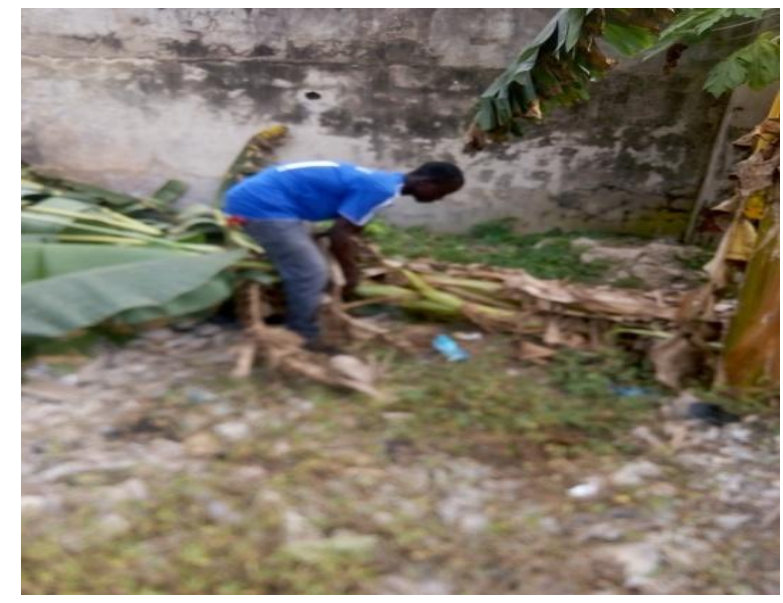

Picture 1. Collection and Storing of Residue
A wide variety of production variables determine the physical and mechanical properties of cement-bonded wood composites. Among those, wood/cement ratio, density, type and percent accelerators used, particle geometry, wood species, amount of water, pre-treatment of wood, chemical composition of wood, composition of cement was reported to be of primary importance (Frybort et al., 2008). The objective of this study was to investigate the inclusion of banana pseudo-stem in cement bonded board, its physical and mechanical properties as reinforcing material was assessed in combination of the residue with Gmelina arborea sawdust from sawmill industry at diverse mixing ratio and different blending proportions.

\section{MethodS \\ Procurement of raw materials}

Banana pseudo-stem residue (Plate 1) was sourced from a farm in Awule rural settlement in Akure, Ondo State, Nigeria, and Gmelina arborea sawdust was obtained from a wood processing company in Akure, Ondo State, Nigeria. The residues were processed at the Wood Composite Laboratory of The Federal University of Technology, Akure, Nigeria. Calcium chloride an additive to increase the strength and improve the dimensional stability of the boards was purchased from a Scientific Chemical Laboratory while Ordinary Portland Cement was purchased from fresh consignment.

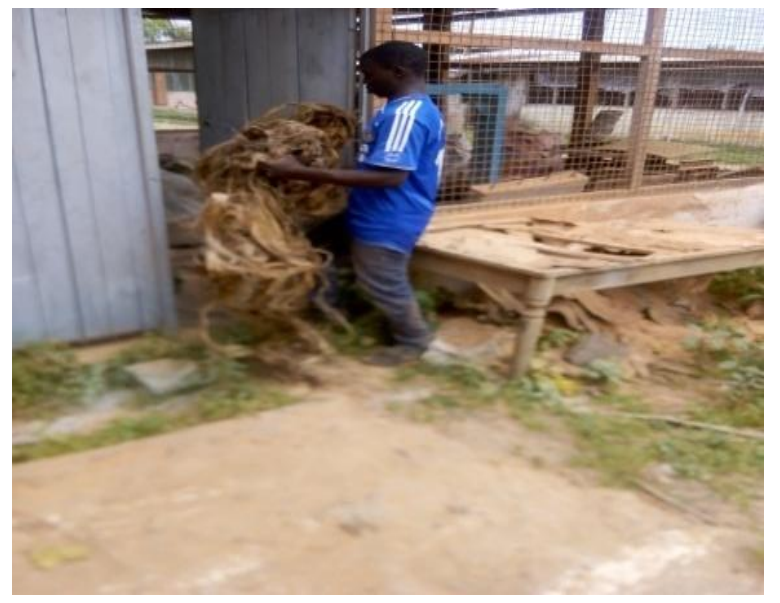




\section{Preparation of material}

A wooden mold of $220 \times 220 \times 8 \mathrm{~mm}$ was constructed at the Department of Forestry and Wood Technology's Wood and Furniture Workshop at the Federal University of Technology, Akure, and utilized as the frame for mat formation.

The Bio-fibre material from Banana Pseudostem was cut to fiber lengths of $50 \mathrm{~mm}$, immersed in water for 72 hours to facilitate the process of fermentation for quality board production. The extracted fibre was milled in a milling machine, washed, and pre-treated in hot water for 24hours to remove the inhibitory content. The fiber was rinsed thrice and sun-dried to reduce the moisture content to $15 \%$, then sealed in a jute-bag for conditioning. Similarly, Gmelina arborea sawdust was pretreated in boiled water for 30mins at a temperature of 900C to remove the inhibitory substances that may likely affect the setting of the cement used as a binding agent (Ajayi, 2005). It was washed and air dried to attain a moisture content of $12 \%$ before utilization.

\section{Board formation}

The blending proportion of 100:0, 90:10, 80:20, 70:30, and 0:100 fibre/sawdust with cement/ material and mixing ratio of $2: 1$ and $3: 1$ were used for the production of the Board. The weight (gram) of the required quantity of banana pseudo-stem fiber and the binding agent (cement) were taken with the use of weighing balance, the chemical additive $(\mathrm{CaCl} 2)$ 3\%, and water was added after which it was mixed in the stated ratio and cast into the wooden-mold frame and covered with polythene sheets to enhance easy removal. They were then pressed to the required thickness. The board was removed after 24 hours and stacked in the rack for 21 days of curing. All sample boards were produced according to the stated method with three replicates each per treatment.

\section{Parameters Tested}

The board edges were trimmed with a circular saw machine to avoid edge effect and then cut into required sizes of $50 \times 50 \times 8 \mathrm{~mm}$ and $195 \times 50 \times$ $8 \mathrm{~mm}$ for Physical and Mechanical tests respectively according to ASTM (2005) Standard for Particle Board test.

\section{Physical test: Water Absorption Test}

The percentage water intake for different mixing ratios was calculated after 24,48 , and 72 hours soaking time using:

WA $(\%)=\frac{w_{2}-W_{1}}{W_{1}} \times \frac{100}{1}$

Where:

$W 1=$ Initial Weight of the board (g)

$W 2=$ Weight of board after immersion in water $(\mathrm{g})$

\section{Thickness Swelling Test}

Thickness swelling (TS) after 24, 48, and 72 hours immersion in water was calculated using;

TS \% $=\frac{T_{2}-T_{1}}{T_{1}} \times 100$

Where:

$T_{2}=$ thickness of the board after water immersion (mm)

$T_{1}=$ the initial thickness of the board (mm).

\section{Linear Expansion Test}

The test-samples were immersed in water for 24, 48, and 72 hours. The Linear change in each sample was measured after immersion. The percentage linear expansion was determined using the formula;

L.E $\%=\frac{L_{2}-L_{1}}{L_{1}} \times 100$

Where

$L_{2}=$ length of the board after water immersion ( $\left.\mathrm{mm}\right)$

$L_{l}=$ initial length of the board (mm)

Mechanical test: Modulus of Rupture Test (MOR) and Modulus of Elasticity Test (MOE)

The two tests were determined by three-point loading on Universal Testing Machine by applying load at the center of each board sample with the aid of an electro-mechanical motor to the point when failure occurred. The ultimate load (P) and the slope were recorded and estimated using:

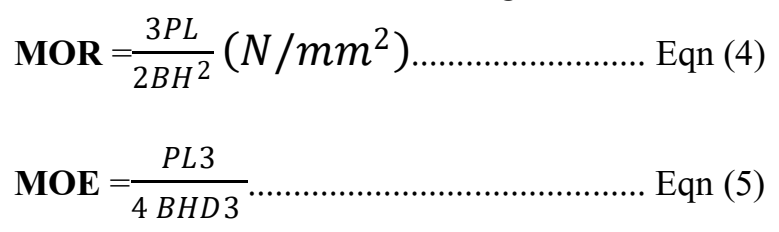

Where

MOR:

$\mathrm{L}=$ Span between centre of support (mm)

$\mathrm{B}=$ Width of test specimen $(\mathrm{mm})$ 
$\mathrm{H}=$ Thickness of test specimen (mm)

$\mathrm{P}=$ Ultimate failure load $(\mathrm{N})$

MOE:

$L=$ Span between center of support (mm)

$B=$ Width of test specimen $(\mathrm{mm})$

$P=$ Ultimate failure load $(\mathrm{N})$

$H=$ Increase in deflection

$D=$ Thickness of the specimen (\%)

\section{Experimental Design}

For the purpose of this study, $2 \times 5$ factorial experiment in Completely Randomized Design with 5levels of factor A (Blending proportion) and 2 levels of factor B (Mixing ratio) replicated three times for each treatment combination.

The experiment was designed to include the following production variables:

1. Board density: $1100 \mathrm{~kg} / \mathrm{m} 3$ (nominal density)

2. Blending proportion: $100: 0,90: 10,80: 20,70: 30$ and 0:100 depicting sawdust to banana pseudostem fibre

Mixing ratio of cement to sawdust at

1. 2:1 and 3:1 depicting cement to mixture of sawdust + banana pseudo-stem fibre

2. Additive concentration at a level of $3 \%$ of cement weight in each board.

3. Pressing pressure: $1.23 \mathrm{~N} / \mathrm{mm}^{2}$

4. Board size: $220 \times 220 \times 8 \mathrm{~mm}$

\section{RESULTS AND DISCUSSION Water Absorption}

The mean values for mixing ratio $2: 1$ after immersion in water for 24 hours ranged between 22.10 and $47.90 \%$, values between 24.87 and $50.93 \%$ were recorded for 48 hours while a range of $26.07 \%$ and $52.93 \%$ were recorded for 72 hours water-immersion cycle.

Similarly, mean values for mixing ratio $3: 1$ after immersion in water for 24 hours ranged between 19.69 and $42.54 \%$ and between 23.44 and $46.81 \%$ for 48 hours while 26.41 and $50.56 \%$ was obtained for 72 hours water-immersion cycle for the blending proportions as shown in (Figure 1) The Analysis of Variance (ANOVA) carried out at 95\% probability level (Table II) showed that mixing ratio, blending proportion and immersion period have significant effect on water absorption after 24 , 48 and 72 hours.

The Duncan Multiple Ranged Test (DMRT) for WA showed that there were significant difference between boards of blending proportion of 100:0,80:20,70:30,90:10when subjected to the three (3) time intervals $(24,48 \& 72$ hours) respectively as shown in Table 4.

Water Absorption is a physical property related to the dimensional stability of the boards, which gives an idea of how cement-bonded boards behave when exposed to severe humidity conditions, it is especially important in boards for external purposes. Wood water relation is the most indicative feature of wood with a major influence on dimensional stability and board durability.

Results obtained for board samples showed increases in the rate of water absorption after 24, 48 and 72 hours cycles from boards produced with $100 \%$ sawdust, mixture of sawdust, and banana stem to boards produced with $100 \%$ banana stem. This corroborates with the findings of Owoyemi and Ogunrinde (2013), which revealed that; "Water absorption decreased with increase M.R while board density increased with increase in M.R." The boards with B.P 0:100 at M.R 3:1 is more porous because of the increased quantity of banana fibrelengths in it. The inter-flake was filled with water thereby opened the void-spaces and contributed to the weight of the boards.

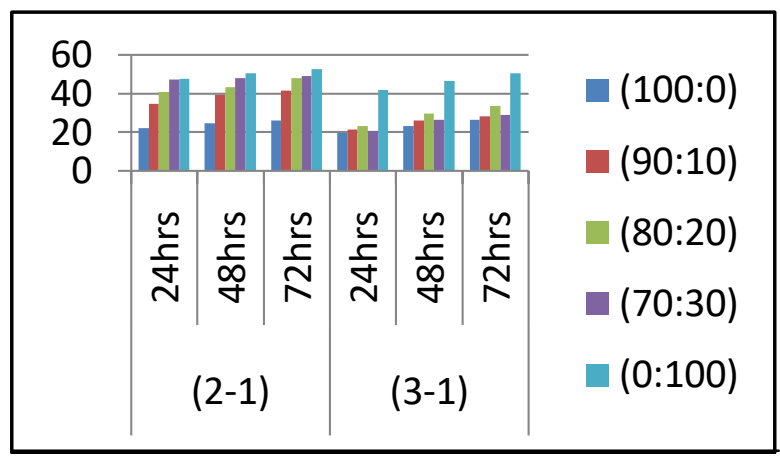

Figure 1: Chart Showing Water Absorption Test 
Table 1: Anova Table for Water Absorption

\begin{tabular}{|c|c|c|c|c|c|c|}
\hline $\begin{array}{c}\text { water } \\
\text { absorption }\end{array}$ & Source of variation & $\begin{array}{l}\text { Sum of } \\
\text { Squares }\end{array}$ & Df & $\begin{array}{l}\text { Mean } \\
\text { Square }\end{array}$ & F-cal & Sig. \\
\hline & Mixing ratio & 2592.02 & 1 & 2592.02 & 25.97 & 0.01 \\
\hline & Blending proportion & 6321.91 & 4 & 1580.48 & 15.84 & 0.01 \\
\hline & Time & 1428.42 & 2 & 714.21 & 7.16 & 0.01 \\
\hline & $\begin{array}{l}\text { Mixing ratio * Blending } \\
\text { proportion }\end{array}$ & 3462.56 & 4 & 865.64 & 8.67 & 0.01 \\
\hline & Mixing ratio * Time & 135.42 & 2 & 67.71 & 0.68 & 0.51 \\
\hline & Blending proportion * Time & 774.71 & 8 & 96.84 & 0.97 & 0.50 \\
\hline & $\begin{array}{l}\text { Mixing ratio * Blending } \\
\text { proportion * Time }\end{array}$ & 472.49 & 8 & 59.06 & 0.59 & 0.78 \\
\hline & Error & 11976.68 & 120 & 99.81 & & \\
\hline & Total & 27164.21 & 149 & & & \\
\hline
\end{tabular}

\section{Thickness Swelling}

The mean values for cement-bonded board of mixing ratio (MR) 2:1 ranged between 0.89 and $1.92 \%$ after $24 \mathrm{hrs}$ immersion in water. For 48 hours, mean values ranged between 1.82 and 2.94 $\%$ while soaking for 72 hours ranged between 2.16 and $3.38 \%$.

For boards with MR 3:1, mean values after 24 hours ranged between 0.59 and $1.98 \%, 48$ hours immersion-cycle recorded values between 1.15 and $3.5 \%$. While 72 hours water-immersion cycle ranged between $1.31 \%$ and $4.00 \%$ (Figure 2). Analysis of Variance carried out at $95 \%$ probability level (Table III) showed that mixing ratio does not have a significant effect on T.S but blending proportion and soaking time have a significant effect on thickness swelling after 24,48 and 72hours.

A follow-up analysis conducted with Duncan Multiple Ranged Test(DMRT) on the boards showed that boards produced with a blending proportion of 100:0 have the highest rate of thickness swelling (i.e. swells rapidly) while there is a significant difference between the other boards of B.P $(80: 20,70: 30,90: 10,0: 100)$ at 24,48 and 72 hours water-immersion cycle (Table 4).
Thickness swelling is a physical property for assessing the dimensional stability of the boards, it shows how cement-bonded boards perform under severe humidity conditions; it is especially useful in boards for external purposes. Thickness swelling value increases with an increase in fibre content of the board and decreases with an increase in sawdust. Similarly, T.S decreases with increasing cement to fibre ratio. This assertion corroborates with the works of Ajayi, (2003) which stated that Cement-bonded particleboard made at B.P 100:0 of Sawdust to banana flakes with M.R 3:1 of cement to cellulosic materials produced the least thickness swelling of $0.27 \%$. This finding is also in agreement with previous work on composites board by Owoyemi and Ogunrinde (2012) on Flexural and Thickness Swelling Properties of Paper Cement Board made from Waste Paper that thickness swelling (TSW) for the boards produced with the highest M.R 2:1 cement paper ratio showed the least thickness swelling". This observation as found in this research-work may be as a result of a reduction in cement paste mixed with sawdust and banana pseudo-stem fibres rendering water to penetrate the uncoated space of the experimental boards. 


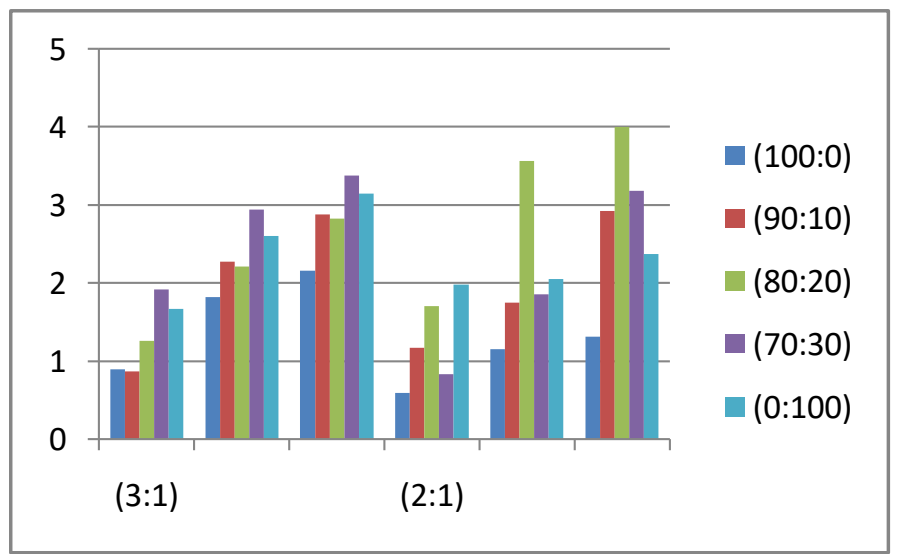

Figure 2: Chart Showing Thickness Swelling Test

Table 2: Anova Table for Thickness Swelling

\begin{tabular}{|c|c|c|c|c|c|c|}
\hline $\begin{array}{l}\text { Thickness } \\
\text { Swelling }\end{array}$ & Source of variation & $\begin{array}{l}\text { Sum of } \\
\text { Squares }\end{array}$ & Df & $\begin{array}{l}\text { Mean } \\
\text { Square }\end{array}$ & F-cal & Sig. \\
\hline & Mixing ratio & 1.0 & 1 & 0.96 & 0.34 & 0.56 \\
\hline & Blending proportion & 30.0 & 4 & 7.51 & 2.63 & 0.04 \\
\hline & Time & 59.5 & 2 & 29.74 & 10.41 & 0.01 \\
\hline & $\begin{array}{l}\text { Mixing ratio * Blending } \\
\text { proportion }\end{array}$ & 16.6 & 4 & 4.16 & 1.46 & 0.22 \\
\hline & Mixing ratio * Time & 0.4 & 2 & 0.19 & 0.07 & 0.94 \\
\hline & Blending proportion $*$ Time & 4.7 & 8 & 0.58 & 0.20 & 0.99 \\
\hline & $\begin{array}{l}\text { Mixing ratio * Blending } \\
\text { proportion * Time }\end{array}$ & 3.7 & 8 & 0.46 & 0.16 & 1.00 \\
\hline & Error & 342.9 & 120 & 2.86 & & \\
\hline & Total & 458.8 & 149 & & & \\
\hline
\end{tabular}

\section{Linear Expansion}

The LE mean values for test-samples produced with a mixing ratio of $2: 1$ after 24 hours waterimmersion cycle ranged between $0.12 \%$ and $0.67 \%$ and L.E mean values of $0.20 \%$ and $0.28 \%$ was determined after test-samples were immersed in water for 48hours while boards immersed in water for 72 hours ranged between mean values of $0.28 \%$ and $0.75 \%$ respectively.

Boards of mixing ratio 3:1 was subjected to a similar linear expansion test and its mean values ranged between $0.10 \%$ and $0.63 \%$ after 24 hours immersion-cycle while the test-samples were determined with mean-values ranged between $0.16 \%$ and $0.77 \%$ after 48 hours water-immersion cycle. Finally, boards immersed in water for 72 hours ranged between mean values of $0.28 \%$ and
$0.75 \%$ respectively for the blending proportions (Figure 3). The Analysis of Variance carried out at 95\% probability level (Table 3 ) show that mixing ratio does not have a significant effect on T.S but blending proportion and time have a significant effect on thickness swelling after 24,48 , and 72 hours water immersion cycle. A follow-up analysis was conducted with Duncan Multiple Ranged Test (DMRT) on the test samples where boards produced with blending proportion of 100:0 have high linear expansion while there is a significant difference between the other boards of Blending Proportion 80:20, 70:30, 90:10, 0:100 after water absorption at 24, 48 and 72 hours cycle (Table 4).

Linear expansion is a function of the performance of cement-bonded boards when used in severe humidity prone environment, boards for 
external purposes are often subjected to this physical test. The relationship between wood and water is the most significant feature of wood with a major influence on dimensional stability.

Linear expansion decreased from boards produced from pure cement and sawdust (B.P
100:0) to boards from pure cement and banana pseudo-stem fibres (B.P 0:100) as a result of the non-inclusion of banana pseudo-stem fibres in the structural integrity of boards produced with only sawdust.

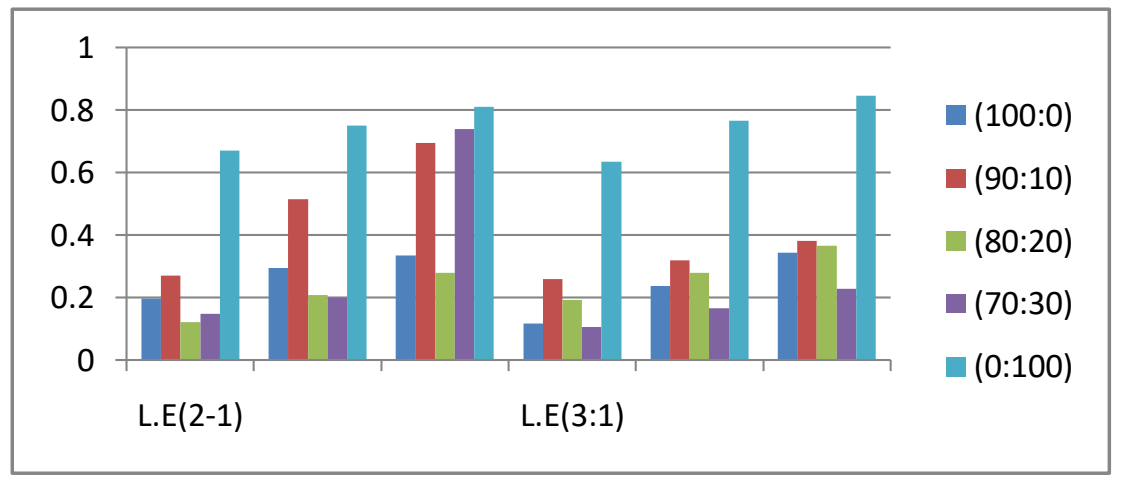

Figure 3: Chart Showing Linear Expansion Test

Table 3: Anova Table for Lineae Expansion

\begin{tabular}{|c|c|c|c|c|c|c|}
\hline $\begin{array}{c}\text { Linear } \\
\text { Expansion }\end{array}$ & Source of variation & $\begin{array}{l}\text { Sum of } \\
\text { Squares }\end{array}$ & $\mathrm{df}$ & $\begin{array}{c}\text { Mean } \\
\text { Square }\end{array}$ & F-cal & Sig. \\
\hline & Mixing ratio & 0.09 & 1 & 0.09 & 1.14 & 0.29 \\
\hline & Blending proportion & 5.86 & 4 & 1.46 & 18.64 & 0.01 \\
\hline & Time & 0.93 & 2 & 0.46 & 5.91 & 0.00 \\
\hline & $\begin{array}{l}\text { Mixing ratio * Blending } \\
\text { proportion }\end{array}$ & 0.28 & 4 & 0.07 & 0.90 & 0.47 \\
\hline & Mixing ratio $*$ Time & 0.01 & 2 & 0.01 & 0.08 & 0.93 \\
\hline & Blending proportion * Time & 0.05 & 8 & 0.01 & 0.08 & 1.00 \\
\hline & $\begin{array}{l}\text { Mixing ratio } * \text { Blending } \\
\text { proportion } * \text { Time }\end{array}$ & 0.05 & 8 & 0.01 & 0.08 & 1.00 \\
\hline & Error & 9.42 & 120 & 0.08 & & \\
\hline & Total & 16.77 & 149 & & & \\
\hline
\end{tabular}

Table 4: Duncan Multiple Ranged Test for W.A, T.S \& L.E

\begin{tabular}{|l|l|l|l|}
\hline Blending Proportion & Water Absorption & Thickness Swelling & Linear Expansion \\
\hline $100: 0$ & $22.76 \mathrm{a}$ & $1.32 \mathrm{a}$ & $0.25 \mathrm{a}$ \\
\hline $90: 10$ & $30.88 \mathrm{~b}$ & $1.98 \mathrm{ab}$ & $0.41 \mathrm{~b}$ \\
\hline $80: 20$ & $38.05 \mathrm{c}$ & $2.64 \mathrm{~b}$ & $0.24 \mathrm{a}$ \\
\hline $70: 30$ & $30.62 \mathrm{~b}$ & $2.35 \mathrm{~b}$ & $0.22 \mathrm{a}$ \\
\hline $0: 100$ & $42.35 \mathrm{~d}$ & $2.26 \mathrm{~b}$ & $0.75 \mathrm{c}$ \\
\hline
\end{tabular}

\section{Density}

The mean values for density of boards produced with cement/fibre mixing ratio of $2: 1$ ranged between 980.00 to $1,140.00 \mathrm{~kg} / \mathrm{m} 3$ while the mean values for density of boards produced with Mixing ration 3:1 ranged between 1,010.00 and $1,360.00 \mathrm{~kg} / \mathrm{m} 3$ (Figure 4) The result of ANOVA (Table 5) showed that blending proportion and 
mixing ratio has a significant effect on the density of the boards produced.

Density refers to the mass or weight of materials per unit volume is very significant in the determination of strength and water holding capacity of the board. These works reveal that as board density increases, WA, TS, MOE, and MOR decreased which corroborates with the findings of Ajayi (2005) that board density has a significant effect on cement-bonded boards reinforced with fibrous materials.

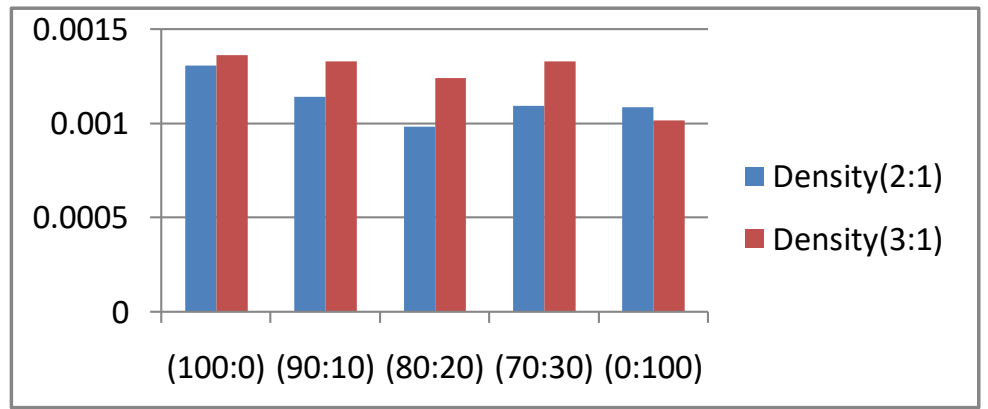

Figure 4: Chart Showing Density Test

Table 5: Anova Table for Density

\begin{tabular}{|l|r|r|r|r|r|}
\hline Density Source of variation & Sum of Squares & Df & Mean Square & F-cal & Sig. \\
\hline Mixing ratio & 2.23 & 1 & 2.23 & 30.52 & 0.02 \\
\hline Blending proportion & 4.87 & 4 & 1.22 & 16.63 & 0.01 \\
\hline Mixing ratio * Blending proportion & 1.90 & 4 & 4.75 & 6.49 & 0.03 \\
\hline Error & 2.93 & 40 & 7.32 & & \\
\hline Total & 1.19 & 49 & & & \\
\hline
\end{tabular}

Mechanical Properties of Fibre-Reinforced $\mathrm{N} / \mathrm{mm}^{2}$ for mixing ratio $3: 1$ by the blending

\section{Board}

\section{Modulus of Rupture}

The mean values for MOR ranged between 2.55 to $7.59 \mathrm{~N} / \mathrm{mm} 2$ for mixing ratio $2: 1$ while the mean values for MOR ranged between 0.55 to 1.46 proportions used for the production respectively (Figure 6). The Analysis of Variance (Table 6) showed that the mixing ratio is not significant on MOR and blending proportion is significant for the Modulus of Rupture.

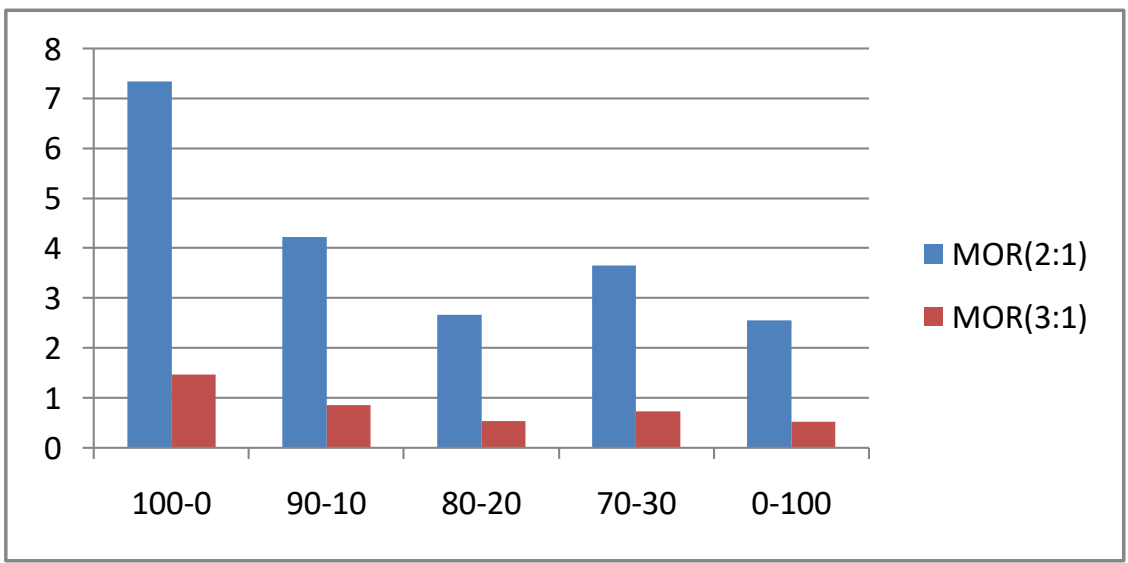

Figure 5: Modulus of Rupture of boards at different mixing ratios 
Table 6: Anova Table for Modulus of Rupture

\begin{tabular}{|lllll|l|l|l|}
\hline MOR & Source of variation & Sum of Squares & Df & Mean Square & \multicolumn{2}{l}{ F-cal } & Sig. \\
\hline & Mixing ratio & 467735.16 & 1 & 467735.16 & 1.70 & 0.20 \\
\hline & Blending proportion & 19280000.00 & 4 & 4820207.77 & 17.51 & 0.03 \\
\hline & $\begin{array}{l}\text { Mixing ratio * Blending } \\
\text { proportion }\end{array}$ & 1909289.49 & 4 & 477322.37 & 1.73 & 0.162 \\
& Error & 11010000.00 & 40 & 275355.26 & & \\
\hline & Total & 32670000.00 & 49 & & & \\
\hline
\end{tabular}

\section{Modulus of Elasticity}

The mean values for MOE for boards with mixing ratio 2:1 ranged between 293.65 to 2367.01 $\mathrm{N} / \mathrm{mm}^{2}$ while boards with mixing ratio $3: 1$ ranged between 250.99 to $2009.28 \mathrm{~N} / \mathrm{mm}^{2}$ for $100-0$ and 0 100 sawdust/fibre blending proportions respectively as used for the production (Figure 6). The Analysis of Variance (Table 7) showed that the mixing ratio had no significant effect on MOE while the blending proportion had a significant effect on the Modulus of Elasticity.

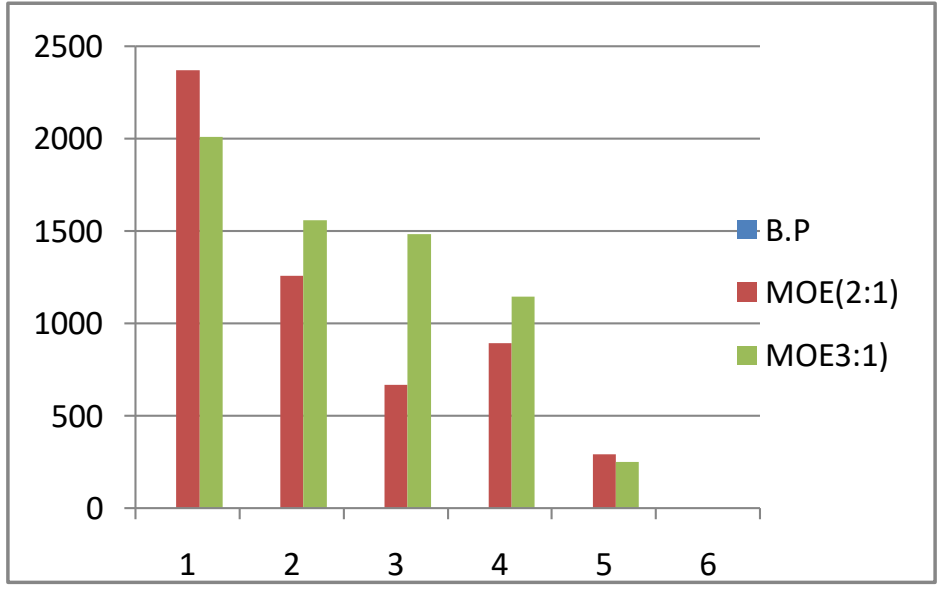

Figure 6: Modulus of Elasticity of boards

Table 7: Anova Table for Modulus of Elasticity

\begin{tabular}{|c|c|c|c|c|c|c|c|}
\hline MOE & Source of variation & Sum & of Squares & df & $\begin{array}{l}\text { Mean } \\
\text { Square }\end{array}$ & F-cal & Sig. \\
\hline \multicolumn{3}{|c|}{ Mixing ratio } & 2.43 & 1 & 2.43 & 1.1 & 0.31 \\
\hline & Blending proportion & & 126.49 & 4 & 31.62 & 13.8 & 0.02 \\
\hline \multicolumn{3}{|c|}{ Mixing ratio * Blending proportion } & 10.88 & 4 & 2.72 & 1.2 & 0.33 \\
\hline & Error & & 91.51 & 40 & 2.29 & & \\
\hline \multicolumn{3}{|c|}{ Total } & 231.30 & 49 & & & \\
\hline \multicolumn{3}{|c|}{$\begin{array}{l}\text { Modulus of Rupture and Modulus of Elasticity } \\
\text { nechanical properties depicting the strength of } \\
\text { rd products, they give an idea of how cement- } \\
\text { ded boards behave when subjected to tensile } \\
\text { ss and suggest the maximum load such boards } \\
\text { withstand before deformation simultaneously. }\end{array}$} & $\begin{array}{l}(50 \mathrm{~mm}) \text { in } \\
\text { filled the } \mathrm{p} \\
\text { the opinior } \\
\text { cement bo } \\
\text { produced } \\
\text { mechanical }\end{array}$ & $\begin{array}{l}\text { structl } \\
\text { space. } \\
\text { Bade } \\
\text { boar } \\
\text { sho } \\
\text { perties }\end{array}$ & $\begin{array}{l}\text { ral integri } \\
\text { This asser } \\
\text { o et al., } \\
\text { d. They c } \\
\text { fibres }\end{array}$ & $\begin{array}{l}\text { of the } \\
\text { n corre } \\
\text { 11) res } \\
\text { ned th } \\
\text { igth he }\end{array}$ & $\begin{array}{l}\text { bards i.e } \\
\text { tes with } \\
\text { arch on } \\
\text { boards } \\
\text { better }\end{array}$ \\
\hline
\end{tabular}

The tests on the board samples revealed that Boards produced with Mixing 3:1 tends to be the strongest due to more availability of short fibres of 


\section{CONCLUSION}

The use of agricultural residues as reinforcers in cement bonded board produced with sawdust has performed best in use. It is also a good strategy towards sustainable forest management and a feasible alternative to curtail the effects of overexploitation of trees thus reducing pressure on the forests. Boards produced with banana-stem fibres have demonstrated good strength properties. The results from this work showed that the physical and mechanical properties of cement-bonded board can be improved when a minimum fibre-lengths included. This research work confirmed the possibilities of utilization of agricultural residues usually disposed of as waste on farms. It revealed that Boards produce from blending proportion 90:10 had better physical performance and high strength properties.

\section{REFERENCES}

1. Adejoba, O.R, S.O Badejo, O.N. Oladele and O.T Babalola. (2008). Evaluation of Cement Bonded Particle Board Production from Lesserused Wood Species. Proceedings of 3rd Int'l conference of West African Society of Agric Engineers \& 9th Int'l Conference of Nigeria Institute of Agric. Engrs. OAU Ile Ife. Pg 261265.

2. Ajayi B. (2003). Assessment of Dimensional Stability of Cement-Bonded Particleboard from Post-Harvest Banana Stem Residues and Sawdust in Proceedings of 12th World Forestry Congress, 21st-28 $8^{\text {th }}$ September 2003 at Quebec City, Canada. Vol.A. Pp.157

3. Ajayi B. (2006). Inorganic-Bonded Manufacture from Yam (Dioscorea rotundata) Strand.10th In. Inorganic Bonded Fibre Composites Conference. November 15th-18th, Sao Paulo, Brazil.

4. Ajayi B. (2010). Durability Characteristics of Cement-Bonded Particle Boards Manufacture from Maize Stalk Residue. Journal of Forestry Research. 22(1):111-115.

5. Ajayi, B. (2002). Preliminary Investigation of Cement-Bonded Particleboard from Maize
Stalk Residues. Nigeria Journal of Forestry. 32 (1), 33-37.

6. American Society for Testing and Materials, (2005). American Society for Testing and Materials, Annual Book of ASTM Standards.100 Barr Harbor Dr., West Conshohocken, PA 19428.ASTM D570-98.

7. Arunwajoye A.S. (2008). Variation in Strength and Dimensional Stability of Plastic Bonded Composites produced from Bamboo.2008

8. Badejo S.O, Bayeiwu R.A, Adejoba O.R and Adelusi E.A., Dimensional Stability of Building Blocks Produced from Wood Waste and Sand. 2011.

9. Bruce R. Hoadley. (2000). Understanding Wood: A Craftsman's Guide to Wood Technology (Newtown, CT: Taunton Press), 235 Bayasi, Z.2003. "Recycled Cellulose Fibres" Concrete Int.25:66-70.

10. Erakhrumen AA, Areghan SE, Ogunleye MB, Larinde SL, Odeyale OO. (2008). Selected Physico-mechanical properties of cement bonded particle board made from pine (Pinus caribea M.) Sawdust-coir (Cocus nucifera L.) mixture. Scientific Research and Essay, 3(5): 197-203.

11. Frybort S, Mauritz R, Teishinger A (2008). Muller U. Cement Bonded Composites: A Mechanical Review. BioResources. 3 (2), 602626.

12. Mantanis, G and J. Berns, Strawboards bonded with Urea Formaldehyde resins. $35^{\text {th }}$ Intl. Particleboard/Composite Mat. Sym. WSU, Pullman, USA April (2001).

13. Mohanty, A.K, M. Misra, \& L.T. Drzal. (2001). Surface modification of natural fibres and performance of the resulting biocomposites: An overview. Composite interfaces, 8 (5), 313-343

14. Owoyemi, J.M., Fuwape J.A and O.S Olaniran. (2010). The role of wood preservation in sustainable supply of forest products. In: Popoola, L; Idumah, F.O.; Adekunle, V.A.J and Azeez, I.O (eds)

15. Rokiah,H., A.H Siti Hazneza, S.Othman, I.Norli, I.M. Hakimi, M.J. Hasnah, and 
U.Salmiah. (2009) Extractable Formaldehyde from Waste Medium Density Fibreboard.. Journal of Tropical Forest Science. 21(1), 2533.

16. Saffari, M. (2011). Effects of Hardener Type and Particles Size on Formaldehyde Emission, 2011 International Conference on Environment Science and Engineering IPCBEE 8:242-244 vol. 96:977-983.

17. Wood Handbook. (1999). Wood as an Engineering Material. Washington D.C.USDA $466 \mathrm{pp}$. 